\title{
Mandatory International Financial Reporting Standards
}

\section{Support Among Trading Companies in Los Angeles:}

\author{
An Analysis
}

\author{
Walid M Masadah (Corresponding Author) \\ Department of Accounting, Hashemite University, Jordan
}

Tel: 011-962-779-760-149. Email: w.masadeh71@yahoo.com

Ahmed Al-Omush
Department of Accounting, Hashemite University, Jordan
Email: ahmed.omush@hu.edu.jo

Fadi Shehab Shiyyab

Department of Accounting, Hashemite University, Jordan

Email: fadi_shiyyab@hu.edu.jo

Received: September 9, 2014 Accepted: September 22, 2014 Published: November 7, 2014

doi:10.5296/rbm.v2i1.6581

URL: http://dx.doi.org/10.5296/rbm.v2i1.6581

\begin{abstract}
The study quantitatively investigated the factors influencing the support for a mandatory transition to the International Financial Reporting Standard (IFRS) by grouping survey data as critical driving factors (benefits) and critical inhibiting factors (obstacles). A strong correlation was found between the level of support, and the benefits, suggesting that the support for IFRS depends on awareness and perceptions about key benefits- ease of financial reporting, transparency, and costs reduction compared to GAAP. Two key obstacles found are the cost and the complexity of transition. Awareness and perceptions about IFRS differ significantly according to scope of business operation. National only companies (NOCs) are not enthusiastic about the advantages of IFRS compared to National and International Companies (NAICs). This study concludes that the advantages of IFRS surpass the disadvantages signifying a greater support. It shows there is a greater possibility for a U.S. mandatory transition to IFRS comes 2015. Further studies are recommended on the effectiveness of the IFRS Adoption Prediction Model (IAPM) that resulted from this study.
\end{abstract}

Keywords: International, financial, reporting, standards, support, trading, benefits, obstacles 
The Security and Exchange Commission (SEC) deferred the scheduled adoption of the International Financial Reporting Standards (IFRS) from the year 2014 to 2015, and it is uncertain if a mandatory adoption will actually take place in 2015 regardless of IFRS global popularity and advantages. The IFRS is very popular around the world and in the last decade as Haina (2008) observed, many companies and many countries in Europe have adopted the standards. While advocates and proponents of IFRS posit that accounting standards unification, harmonization or convergence to IFRS standards boosts the quality and comparability of corporate financial disclosures (Haina, 2008; Half, 2009), that may not be the perception among many companies in the Unites States. Studies suggest that in spite of the numerous advantages of the IFRS, many companies in the U. S., even those engaged in international business, seem to be reluctant in adopting IFRS; only $49 \%$ of 2,500 company executives surveyed in a study showed interest in adopting a switch to IFRS (Chasen, 2010). However, the U.S. Securities and Exchange Commission (SEC) has declared that companies in the U.S. could start using International Financial Reporting Standards (IFRS) by 2015, an extension of the previous plan, which allowed some companies to voluntarily do so before 2014 (Chasen, 2010).

Identifying the major internal causes of reluctance in the adoption of IFRS among corporations, the external forces for or against the adoption of IFRS through contextual survey of corporations has become crucial at this point.

The problem is that contrary to expectation, the United States unlike many advanced nations in the world is yet to adopt International Financial Reporting Standards (IFRS). It seems unlikely that the United States will not adopt the International Financial Reporting Standards in 2015 (Asongu, 2008; Barniv \& Fetykov, 1997). However, the doubt still lingers that the 2015 goal might not be met because of two reasons. First, the benchmarks for adoption set by Security and Exchange Commission (SEC) are yet to be met, the benchmarks are part of the goals carried forward from 2011. Second, there is an apparent reluctance among US executives about IFRS transition moves, and half of them are not in support of IFRS (Barniv \& Fetykov, 1997; Chasen, 2010). Delays and postponement have shrouded the move to mandatory adoption in the United States, and consequently many firms do not see the possibility nor take it seriously, especially small firms. There is great concern about the level of awareness on the advantages, disadvantages, obstacles, and most importantly the preparedness for IFRS (Deloitte , 2011; Deloitte, 2008; Lejeune, 2010). Many studies (Barniv \& Fetykov, 1997; Choi \& Meek, 2008; Daske, Hail, Leuz, \& Verdi, 2008) have followed the IFRS issue, but few systematically and analytically examined the forces for and against mandatory adoption, in a way that provides facts about the IFRS adoption possibility or probability, which is essential for prompt decision-making and preparation by many companies.

Regardless of acknowledgements of the benefits, the Securities and Exchange Commissioner Kathleen L. Casey, hinted "the possibility of opting out for issuers, perhaps on a permanent basis" and the continuation with U. S. GAAP, as cited in Deloitte (2011, p. 1). Continuation with U.S. GAAP is an issue for small reporting companies, many of which reside in Southern California and have no international operations or aspirations. Small reporting companies with no international operations see a transition to IFRS as imposing costs on them without providing them with any corresponding benefits, Kathleen further noted. The whole scenario makes the possibility of mandatory adoption look bleak and unlikely. There are now many opposing views, with remarkably two prominent ones. The two prominent views are: (a) firms in favor of a mandatory adoption of the International Financial Reporting Standards 
(IFRS) on one side, and (b) those against adoption of IFRS, who besides rejecting adoption at the initial stage, are now requesting for a provision for opting out of IFRS not only at the initial stage but permanently (Deloitte , 2011; Deloitte, 2008; Lejeune, 2010).

The outcome will depend on how the forces for and against IFRS outweigh each other, and can be predicted through studies, such as a force field analytical study. Predictive and speculative studies play a huge role in the financial and accounting world in swaying opinions, views, action, and support of initiatives, just like in the stock market (Joseph, 2011). As stated earlier, few studies have systematically examined the IFRS adoption in a method that presents facts and dominant factors in favor and against mandatory adoption of IFRS as they work together in concert to sway decisions and predict what will happen come 2015 . The need for systematic and analytical studies to enable decision-making about the IFRS issue, as it affects small companies has been paramount. So far, it seems IFRS has come to stay, but whether it will be mandatory can only be predicted at this time, by looking at the possibility in terms of benefits and demerits or advantages and disadvantages and how they will sway the support for IFRS. Thus the following questions were asked in this study.

1) Do perceived advantages of transition to IFRS outweigh its perceived disadvantages among trading companies to support IFRS transition?

2) Does the perception about advantages and disadvantages of transition to IFRS differ significantly between businesses who operate internationally and those that solely operate nationally in consideration of scope of business operation?

3) Do the Perceived advantages of transition to IFRS in companies with international operations correlate positively with the support for IFRS adoption?

\section{Definition of Terms}

General Accepted Accounting Principles (GAAP). GAAP is a set of accounting guidelines or standards for financial recording, presentation and reporting, based on accounting models, principles, and industry tailored instructions, with the purpose of ensuring transparency and uniformity from one organization to another. The United States Securities and Exchange Commission (SEC) requires the use of GAAP in financial statements and reporting for government agencies and for companies.

International financial reporting standards (IFRS). IFRS means a set of international accounting standards, designed by the International Accounting Standards Board (IASB) stating how specific types of transactions and other dealings should be reported in financial statements. IFRS replaced the older International Accounting Standards (IAS) issued in 1973 and replace in the year 2000 (Doupnik \& Perera, 2007; Forgaty, 2008; Investopedia, 2012).

Force field analysis. Force field analysis is a technique for analyzing change in an organization or system, in which the potential for change is measured by the pressures for change (driving forces) versus the pressures opposing change (restraining forces). Thus, change occurs when the driving forces exceed the restraining forces (Smith, 2011; Kurt, 2012).

Certified public accountant. Refers to people that have passed the national uniform examination, who met the requirements of the stated board to work as accountants with a state license.

International accounting standards board (IASB). The IASB is an independent standard setting-body, backed by the International Accounting Standards Committee foundation as the trustee (International Accounting Standards Board, 2009).

Total Quality Management (TQM). TQM is a philosophy of continuous improvement in 
aspects of an organization, including accounting with the goal of not only making quality products but also of rendering quality accounting services or information, which includes quality accounting statements that are understandable, swiftly accessible at a reasonable cost, transparent, made possible by IFRS (Hill, 2008 ; Wali \& Younes, 2010).

Knowledge management. Refers to structured strategies and procedures used by organizations often called learning organiztionas to identify, create, represent, distribute vital information or knowledge in order to create new knowledge, insights and experiences that are beneficial (Albers \& Brewer, 2003; Bou-Liusar \& Segarra-Cypress, 2006;Skyrme, 2002).

\section{Literature Review}

Many studies have focused on the advantages of IFRS, the convergence between GAAP and IFRS and the position and progress of the United States toward this issue. However, very few studies if any have directly probed three important factors, the awareness/knowledge of companies in the U. S. on the advantages or disadvantages of IFRS, the corporate perception of the obstacles they will face in the IFRS transition process, and the likelihood of a mandatory adoption in 2015. These are significant factors for planning to overcome the obstacles of IFRS transition. They are regarded as strong determinants for accomplishing or fulfilling the 2015 IFRS transition goal, and reviewed from a micro and macro standpoint under three headings: (a) advantages of a transition to IFRS (b) disadvantages and obstacles of a transition to IFRS, and (c) force field analysis. The advantages of IFRS adoption as well as bodies that support the move were addressed under the first heading, while the disadvantages, obstacles and agencies or interest groups against the adoption were discussed under the second as the obstacles to IFRS. How the advantages, disadvantages or obstacles, as forces work against each other and sway the support for IFRS is discussed under the force field analysis.

\subsection{Micro Advantages}

The micro advantages of IFRS are the small but significantly important benefits derivable from a transition to a mandatory adoption of IFRS, that can influence the support for a transition or adoption of the IFRS. Though the adoption of IFRS by 2015 is uncertain, most U. S. companies will have to plan ahead to meet the Security and Exchange commission (SEC) mandate by 2015, when companies will be expected to fully implement the International Financial Reporting Standards (IFRS). According to Chasen (2010) companies less eager, to change to IFRS may be those with less global footprint or companies not engaged in international business, who do not see great advantages. Deloitte (2008) described some of the benefits of IFRS as follows:

1) More efficient use and availability of resources -IFRS facilitate the development of standardized training programs, eliminate divergent accounting systems, and could reduce third party fees associated with local statutory reporting.

2) Improved controls - IFRS allow for greater control over statutory reporting, thereby reducing risks related to penalties and compliance problems at the local level. Many local statutory reports are prepared through a manual conversion from U.S. GAAP. Often there is no worldwide "owner" for statutory reporting.

3) Better cash management -Dividends that can be paid from subsidiaries are based on local financial statements. A change from local GAAP to IFRS can have significant effects on cash dividends, allowing a consistent standard across countries that can improve cash flow planning (Deloitte, 2008, p. 12).

Above benefits are examples of the micro advantages of IFRS transition, which may vary in 
public compared to private companies because, private companies seem to be more cautious in supporting changes, thus the perception of the advantages of IFRS adoption, which may or may not differ significantlyin public versus private companies was examined from their perception of the IFRS benefits.

Public company benefits. Publically traded firms in the United State have a better advantage and stand to benefit significantly by adopting IFRS, unlike privately owned companies, because they are already in the international business and have international branches. IFRS adoption means having uniform records under one standard, instead of two separate standards, which will enhance interior communications, quality of reporting and management decision-making (Michael, 2011). Michael (2011) states that "adopting IFRS it will level the playing field by making U.S. companies better understood in the global marketplace as investors, and management will now be able to accurately benchmark its performance against peers throughout the world; helping to gain access to additional capital and opportunities"

Private company benefits. For most private companies new to IFRS, the adoption process comes with an unwelcome cost, which many think does overrides the benefits. These costs come in the form training, software upgrades, consulting and time. Accountants will need to be educated in IFRS and its impact on the company's financial reporting systems, and these actions will burden private companies in the short run. However, in the end private companies will benefit like public companies. Some companies are afraid to go into international business because of dual reporting standards, and will see IFRS as an opportunity for growth, and venture into the international market. Companies with plans to do business in other countries that have adopted the IFRS will benefit so much. For example, Canada will require IFRS reporting in 2011 and Mexico, which is now reporting on IFRS and is committed to a mandatory requirement from 2012 (Michael, 2011). Seeking opportunities in foreign market for engagement will be made easier with reporting obstacles eliminated. This eliminates the struggles with the issues of growth in overcrowded internal U.S. markets as local companies venture into international markets.

\subsection{Macro Advantages of IFRS}

The global and volatile nature of business today, especially in the flourishing international business demands high quality financial information or financial information that is accurate, reliable, transparent, less costly, understandable and quickly accessible for swift decision making that is critical for success in a highly competitive global market (Byers,2012; Mazboudi, 2012). Financial information provided by companies that help investors includes balance sheets, income statements, cash flow statements, annual statements, and description of operations and engagements (Schroeder, Clark, \& Cathey, 2009). Many American companies as investors or prospective investors in international business need high quality financial information rapidly, especially information without the delays of reconciliation of financial statements to the accounting rules of the countries in which they are seeking capital, or to identify reporting differences to determine investment viability (Neel, 2011; Schroeder, Clark, \& Cathey, 2009; Yip, 2010). All businesses regardless of country of origin see the need to eliminate the obstacle of having national accounting standards, and to replace them with a universal or harmonized international accounting standard through the IFRS adoption process, in the global economy (Vann, 2012). The goal is to constantly improve the quality of an accounting service or product, by improving accuracy and reliability, improve transparency, reduce cost, and make information readily available for swift decision making between and among member nations as an asset for global competition and success in the global market (Bou-Liusar \& Segarra-Cypress, 2006; Half, 2009; Hermastho, 2009; Mazboudi, 2012; Vann, 2012). 
The international market is likened to the last frontier of business expansion, improvement and success for many companies and nations. And in coming together and seeking to constantly improve accounting information, products and services, nations and their companies that adopt the International Financial Accounting Standards (IFRS) could be likened to responding to the principles of Knowledge Management (KN) and Total Quality Management (TQM). The TQM principles when applied to the IFRS goals is based on shared goals and success made possible through constant consultation among member nations to share information and improve product or service quality beneficial to members as a survival tool in a volatile global business world. To the U. S. companies doing international business, it is expected that the concept of TQM is imperative for their success and should include a total push for the removal of the obstacles to sound investment decisions in the international market, through support for the adoption of the IFRS. To the United States as a nation, it means a change from Generally Accepted Accounting Standards to protect not only national interests, but also the interest of her companies (GAAP) to IFRS (Schroeder, Clark, \& Cathey, 2009).

On a much narrower level, for accountants, Knowledge Management (KM) and Total Quality Management (TQM) are two conventional business concepts that justify a change to IFRS, as both advocate better performance through service quality improvement. It is also the main goals for having a uniform and improved financial reporting standard under IFRS (Bou-Liusar \& Segarra-Cypress, 2006; Half, 2009; Hermastho, 2009; Wali \& Younes, 2010). Knowledge Management (KM) means structured strategies and procedures such as the IFRS structured procedures for information generation and reporting that assist in identifying, representing and distributing vital information or knowledge in order to create insights and experiences that are beneficial in business (Albers \& Brewer, 2003; Bou-Liusar \& Segarra-Cypress, 2006; Skyrme, 2002). Accountants' need quick access to accurate and reliable knowledge or information to carry out their function effectively and this is facilitated by IFRS, which in addition makes their work easier as no time is spent on identification and reconciliation accounting differences (Choi \& Meek, 2008 Insik, 2009; Skyrme, 2002; Vann, 2012; Wallace, 2010). Accountants, especially those involved in international accounting, need a sound knowledge of and access to information on standards, guidelines and practices that a company follows when making foreign investments decisions in international business activities (Choi \& Meek, 2008; Doupnik \& Perera, 2007; Schroeder, Clark, \& Cathey, 2009).

Thus, the decision by a nation to adopt IFRS is deemed a Total Quality Management decision, because the move by nations in coming together to generate common, and innovative ways of recording and presenting accounting information in a transparent and comparable way, to the benefit of all and to improve organizational performance is considered not only a TQM approach, but also a knowledge management approach, relevant in the field of accounting (Choi \& Meek, 2008; Doupnik \& Perera, 2007; Schroeder, Clark, \& Cathey, 2009; Insik, 2009; Peng, 2009; Pearce \& Robinson, 2007).

As we have seen, IFRS not only provides a forum for product or service quality improvement, but also provided a channel for tapping into the development of sound information, readily available to member nations and companies for sound investment decisions. This is in line with the concepts of Knowledge Management (KM) and Total Quality Management (TQM), not only for product or service quality improvement, but for the gerneration of sound information for sound investment decisions-making across national borders. From this perspective, the concepts of Knowledge Management and Total Quality Management together illuminate the understanding of the need for change, to adopt IFRS. How companies and nations support or oppose it based on the perceived mutual benefits derivable from the 
provision of high quality product or service needed for survival in competitive international environment, is for many the driving force behind the support and adoption of IFRS.

Adopting the International Financial Reporting (IFRS) involves change by nations from their current accounting standard to IFRS, especially nations and companies seeking IFRS benefits for a better performance in the international market. Change for the United States means a change from GAAP to IFRS, which is necessary because it means getting rid of obstacles or barriers to change. It also means an inclination to the benefits resulting from the enhancement of the quality, value and timeliness of accounting information that makes the need to allow a change to IFRS to occur compelling (Bolman \& Deal, 2003; Burke, 1992; Mazboudi, 2012; Vann, 2012). Change to IFRS could result in a competitive advantage for the U.S, and the reason behind the eagerness of many executives to transform early to IFRS before 2015 (Daske, Hail, Leuz, \& Verdi, 2008; Haina, 2008; Half, 2009). Companies can gain a competitive edge in the market place, the earlier they transit to the IFRS, if qualified for voluntary adoption, before 2015 in the US, since for example research shows increased market liquidity, reduced cost of capital are some of the benefits of adoption of IFRS (Daske, Hail, Leuz, \& Verdi, 2008; Sila, 2007). Staying ahead of competition will soon mean voluntary adoption of IFRS before 2015, especially for companies with many global outlets, such as Levis Strauss. Studies on the IFRS and TQM, must consider contextual factors, such as human behavior, human characteristics and tacit factors, and environment to be authentic (Daske, Hail, Leuz, \& Verdi, 2008; Hill, 2008; Hermastho, 2009 Sila, 2007).

\subsubsection{Disadvantage (Obstacles) of IFRS Adoption in U. S.}

Many obstacles hinder the transition to IFRS as many recent studies indicate. These obstacle are: (a) poor knowledge of IFRS procedures and techniques, and lack of resources, (b) cost. Lejeune (2010) noted that most certified public accountants (CPAs) in the United States lack IFRS education and work experience. Lejeune's quantitative descriptive study in a survey of 436 CPAs made some remarkable discoveries. Most accountants indicated they need education on the following: financial statement preparation and presentation, especially for small and medium size entities, foreign currency transactions, financial statements translation, and IFRS technical update (Lejeune, 2010; Peng, 2009; Propper \& Lipshitz, 1998).

Lejeune's study confirmed findings by previous studies by Deloitte (2008, p.6), which cut across many industries. Deloitte found that thirty percent of the respondents would consider adopting IFRS, 10 percent showed they had insufficient knowledge, 18 percent were undecided and $42 \%$ would not consider IFRS at all, and it does appear that not much has changed between 2008 and 2010 in peoples interest in adopting IFRS.

\section{Force Field Analysis}

Force Field Analysis (FFA) is a systematic procedure for investigating the influence of

some factors on the need for change in a complex situation based on the amount of force they exert on the status quo, such that forces supporting the status quo are called restraining forces, and forces supporting a change in the status quo are called driving forces. These forces or factors can be people, groups, resources, beliefs, attitudes, traditions, rules or laws, values, needs, desires, and so on (Kent, 2012). Adopting IFRS means change, and the need to adopting the IFRS has presented a complex situation in which some people prefer the old GAAP (status quo) and some prefer the IFRS (change). While some people dislike the uncertainties about what IFRS may bring, such as transition costs, training needs, and the convenience of the old GAAP system they have mastered, others see the need for a change to 
IFRS. It is for the advantages IFRS may bring, in reducing the cost of translation of financial documents, comparability, reduction of delays, and competitiveness in the global market that many see IFRS adoption as deserving. As a tool for managing change, the Force Field Analysis helps identify those factors that must be addressed and monitored if change is to be successful. Force Field Analysis (FFA) can be applied in many situations; it can be used to understand the forces for and against an idea, and to explore how people may oppose or support an idea (Creating Minds, 2010; SkyMark, 2012). Thus, FFA was used to explore how people oppose or support the adoption of IFRS standards, following the procedures in Kent (2012) to define the problem, establish the change objective, identify the driving and the restraining forces, and to develop a strategy for change (P. 1).

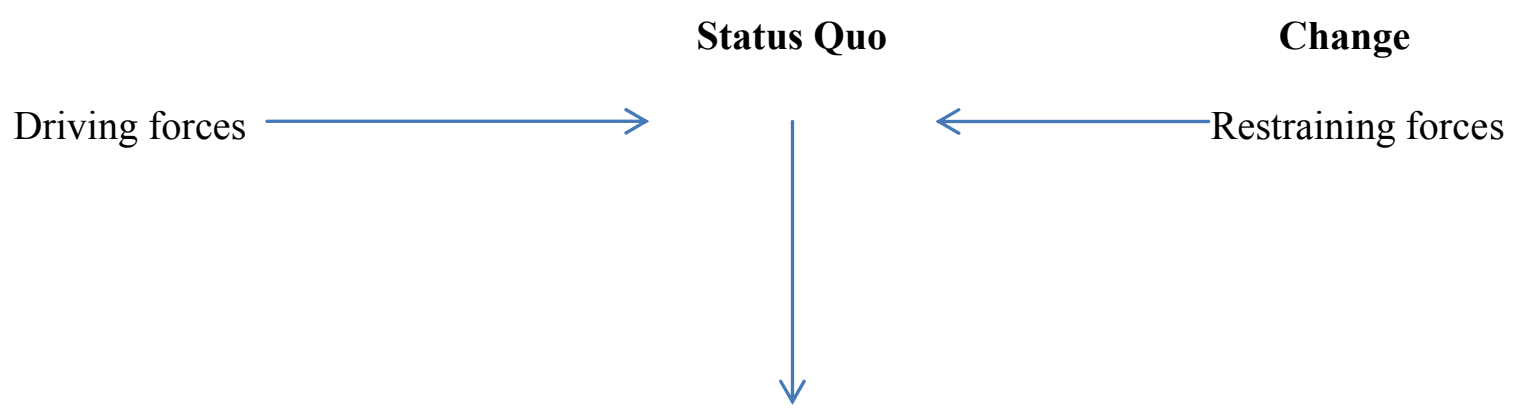

GAAP

IFRS

Source: Emulated from Kenth (2012), http://literacy.kent.edu/eureka/strategies/force field analysis.pdf

Thus Force Field Analysis (FA) provides a platform for not only understanding and predicting a change situation, but for developing or prescribing a comprehensive change strategy upon which recommendations of the study of a situation can be based (Kenth, 2012; SkyMark, 2012). That is why SkyMark (2012) describes Force Field Analysis as a simple and powerful method for clearly understanding the forces that drive and forces that resist a proposed change that can be diagramatically represented by outlining the forces in two column or two-row form, with driving forces listed in the first column or row, and restraining forces in the second. One of the advantages of Force Fieild Analysis (FFA) is that it helps to identify and list the forces or list the support for an idea such as the adoption of the International Financial Reporting Standads (IFRS) by the United States, making it clearer to understand and to plan further action.

\section{Summary of the Key Points}

In spite of the advantages of the IFRS, many companies in the U. S., even some that are engaged in international business seem reluctant in adopting IFRS. Only about $49 \%$ of company executives are interest in a switch to IFRS (Chasen, 2010; Half, 2009). Identifying the causes of reluctance in the adoption of IFRS among corporations has become crucial at this point as the clock ticks closer to 2015 , and as there is a looming uncertainty that adoption might not happen because many of the adoption benchmarks have not been met (Asongu, 2008; Barniv \& Fetykov, 1997; Chasen, 2010; Haina, 2008; Half, 2009). The uncertainty about IFRS adoption has given rise to the crucial need for a study of the obstacle adoption 
and the factors in favoring adoption as perceived advantages and perceived obstacles. Information generated from the study was use to determine how perception about IFRS adoption varies among companies given scope of business operation (national or international or both) and to forecast the level of support for an IFRS transition and the likelihood of adoption come 2015. The next section discusses the findings and implications of the study.

\section{Findings and Implications}

Preliminary findings from this study indicate that the perceived advantages of transition to IFRS overshadow the perceived disadvantages among trading companies in southern California. This means or implies that trading companies are more likely than not to support a mandatory transition to IFRS by the United States, and leaves much hope for the realization of the IFRS mandatory adoption goal come 2015. This finding negates suggestions that countless companies in the U. S, including those involved in international business demonstrate reluctance in their support for IFRS, in spite of the benefits as only about $49 \%$ show interest (Chasen, 2010). Chasen's study was three years earlier, and the question is whether it is possible that between the year 2010 and 2013 a positive change in awareness and support for IFRS has taken place? Yes, at least in trading companies in Los Angeles California where data for this study was drawn from. Another important revelation from this study is that cost of conversion and complexity of conversion are the two main obstacles or disadvantages limiting the support for IFRS adoption among the trading companies studied, which validates findings by Deloitte (2008) where 43 percent of companies surveyed indicated potential cost and complexity of changing to IFRS as the most significant hindrances to adoption. In the same vein, the ease of reporting and transparency of financial data were revealed as two main advantages driving the support for IFRS just as was noted by Michael (2011). It is clear that these views differ according to industry, level of education and awareness, gender, and scope of business operation (Deloitte, 2008; Lejeune, 2010; Peng, 2009; Propper \& Lipshitz, 1998). Thus, to avoid a sweeping assumption about the support for IFRS, a breakdown of this finding by demographics, such as type of industry and scope of operation, level of education and job position of respondents, was done to see if the level of support remains the same.

Second among the key the findings from this study is that the perceptions about the advantages and disadvantages of transition to IFRS differ significantly according to scope of business, and so is the support for IFRS. Scope of business refers to doing business internationally and or doing businesses nationally only or both. Finding confirm assertions that businesses or companies with minute or no international business, whose operations are mainly national, are seemingly less enthusiastic about IFRS, as they see little or no benefits or advantages the adoption of IFRS brings to their operation (Chasen , 2010). 


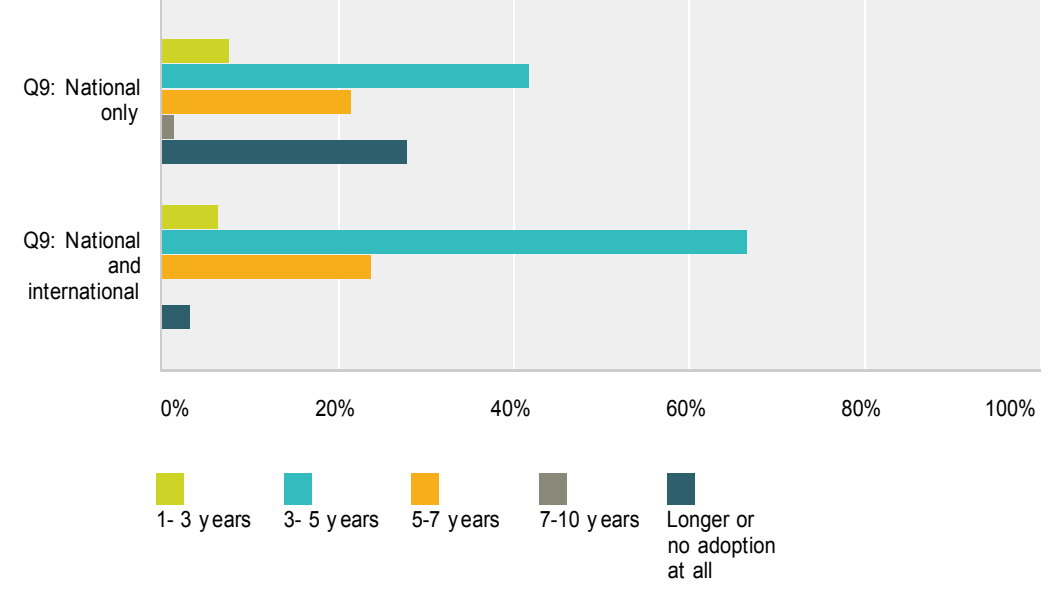

Other factors that explain the differences in the levels of support for IFRS and enthusiasm for its adoption in National Only Companies (NOCs) versus National And International Companies (NAICs) are that NOCs portray lower levels of IFRS awareness, training on IFRS, and have fewer academically educated employee, including lesser number of corporations, than NAICs. Invariably, greater appreciation and support for IFRS comes with more training, awareness, education, which corporations are more capable of financing and emphasizing, than sole proprietors, partnerships or limited liability trading companies that are common in NOCs.

Above findings imply that to beef up suppor for IFRS, and provide greater assurance for the support of its mandatory adoption come 2015, the levels of IFRS awareness, education and training about IFRS in NOCS will have to be boosted, since these are factors were found to correlate with the perception of the advantages of IFRS and invariably its support. It is also citical to beef up the the levels of IFRS awareness, education and training about IFRS, in NAICs as well, to have a balanced effect toward the realization of IFRS adoption in the United States. This effeort will involve educational institutions to teach and create awareness about the advantages, trading companies training employees on IFRS, the government offereing incentives for training and creation of awareness about the benefits, and more convincing research about these bnefits and advantages of IFRS.

Another key finding is that there is a positive relationship between scope of business operation and the support for IFRS. Responses on perceived advantages of a transition to IFRS in companies with international operations were found to correlate positively with the support for IFRS adoption. This further validates the assertion that the creation of greater awareness about (a) the advantages of IFRS, and (b) that NOCs are potential NAICs, and will more than likely transform into NAICs given profitability and opportunity, will enhance the effectiveness of campaigns for the support of IFRS. There is a high level of agreement on three key factors as reasons for the support of IFRS. These factors are the removal of barriers to trade, transparency and comparability of accounting information, and are the selling points for gathering support for IFRS. 


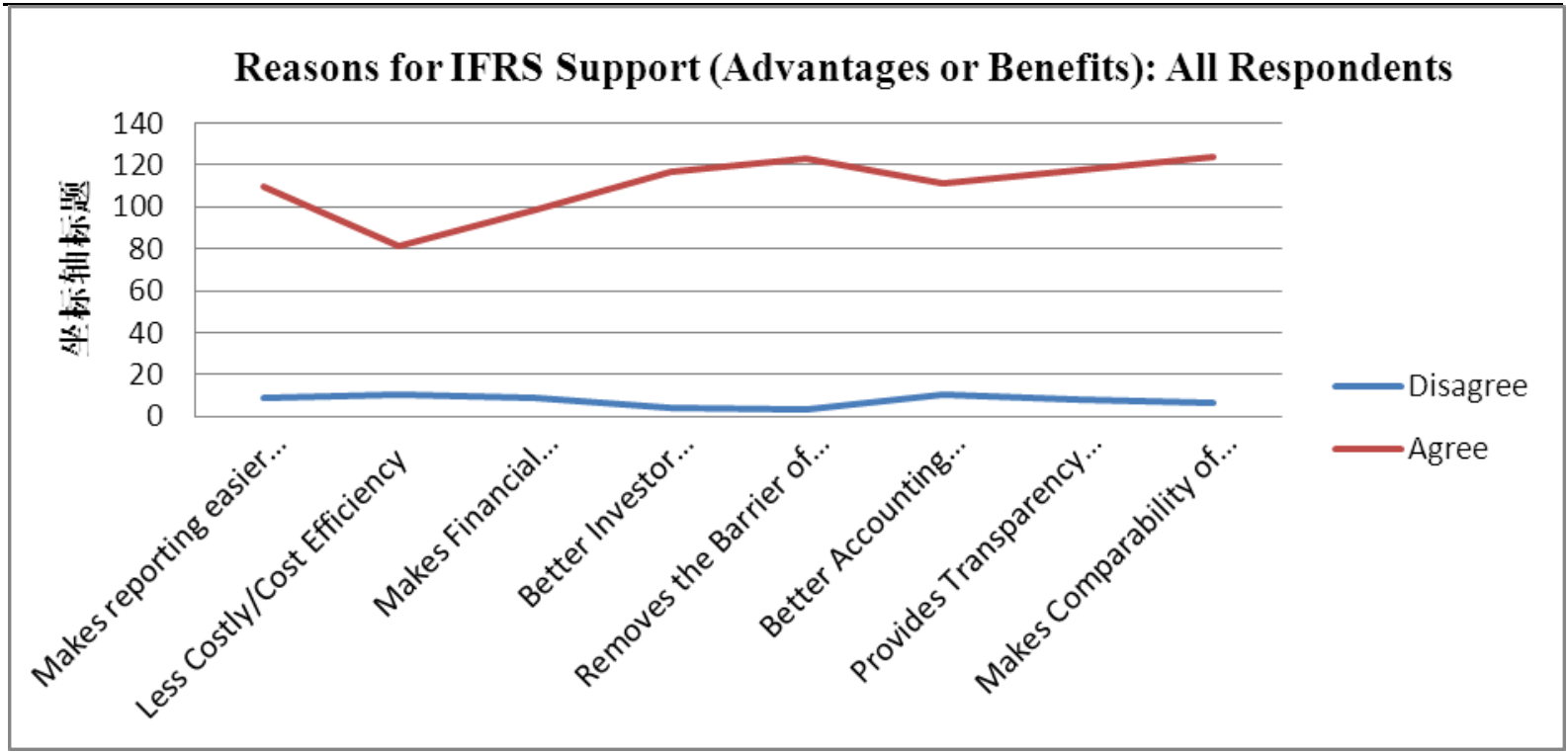

Figure 1: Advantage Factors influencing IFRS Support

On the other hand, three factors are mostly responsible for disagreements, and poor support for IFRS, which are, cost of conversion, complexity of conversion, and poor knowhow and awareness.

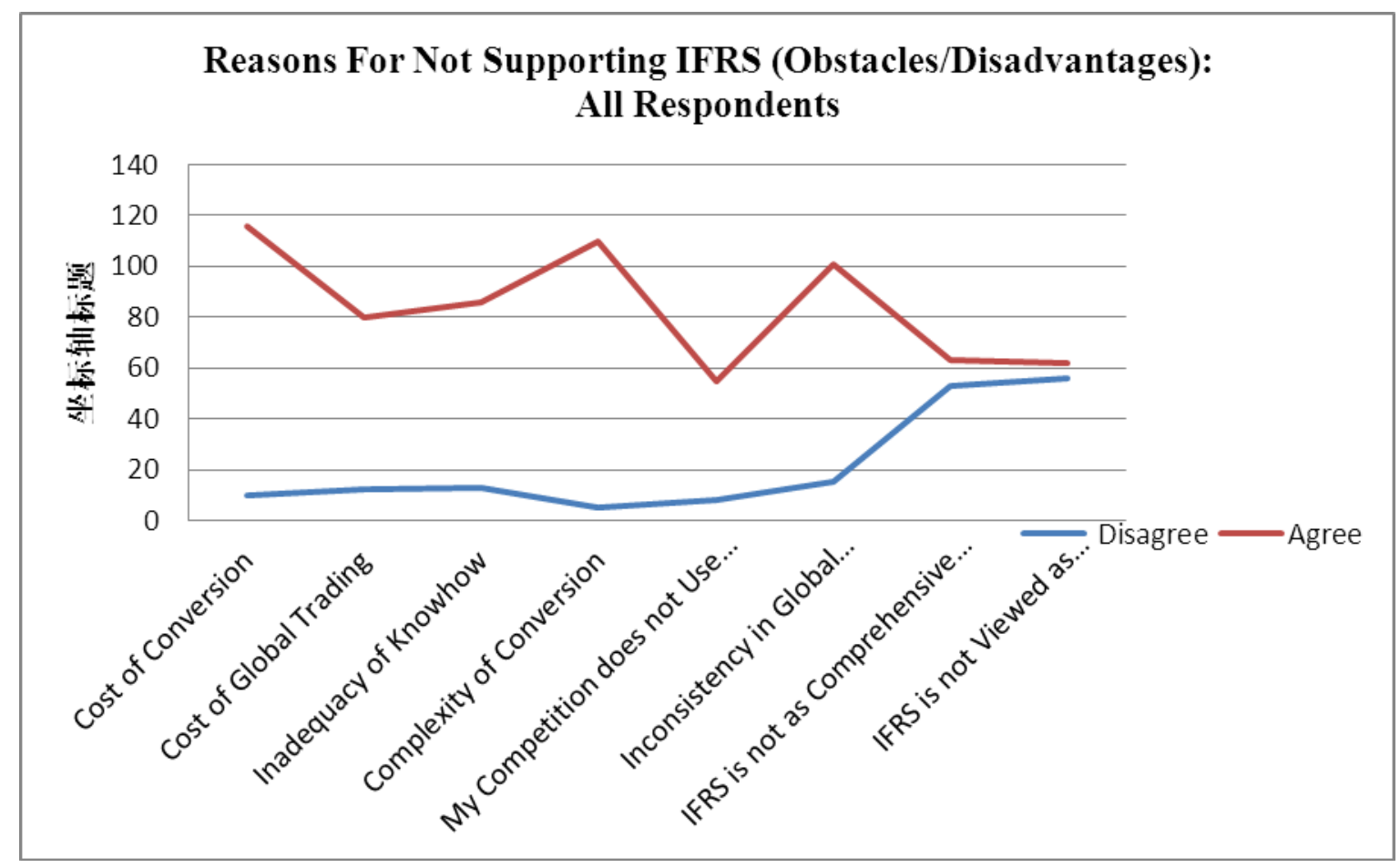

Figure 2: Disadvantage Factors Influencing Supporting for IFRS

Generally the coast seems to be clearer this year than in the past, and doubts about the possibility of a United States adoption of IFRS are gradually eroding, as findings from this and other studies (e.g. Legotte, 2012) have portrayed. The possibility of a mandatory 
adoption highlights the importance of addressing the preparedness of companies and the American higher education for IFRS, as 2015 draws nearer and the possibility become more obvious. The question that needs to be answered is how companies and the United States colleges and universities are prepared for the change? Have curricula changes been made, faculty ready, and most importantly do higher education institutions and companies in the U.S. really anticipate this change and believe it will happen? What have universities and companies in the United States done to prepare bookkeepers, accountants, finance managers, financial controllers, CPAs, and CFO's for the change? Findings from this study make the reality of IFRS adoption more obvious, and imply that there is the urgency for companies, colleges and universities to respond to the coming of IFRS adoption. Not only academic institutions and trading companies, but also banks, credit unions, insurance companies, securities dealers, mutual funds, and investment banks.

\section{Conclusions}

Based on the findings from this study nine conclusions were reached about the mandatory international financial reporting standards support among trading companies, particularly trading companies in Southern California.

1) The support for IFRS mandatory transition among trading companies depends on their perception about the benefits and advantages of IFRS. This conclusion was made because data on the level of support for IFRS shadowed or trailed data on the perceptions about IFRS benefits or advantages.

2) The perception about IFRS benefits and advantages is influenced by three most critical driving factors, which are: (a) that IFRS makes financial reporting easier than GAAP, (b) IFRS provides transparency of financial reporting, and (c) removes the barriers and costs of conversion.

3) The perception about IFRS obstacles, hindrances or disadvantages depends on two most critical opposing factors, which are: (a) cost of conversion, and (b) complexity of conversion.

4) The perceptions about the advantages and disadvantages of transition to IFRS differ significantly according to scope of business operation, and so is the support for IFRS mandatory adoption. Scope of business operation refers to doing business nationally only, on the one hand, and doing business both nationally and internationally.

5) Companies doing business nationally only, referred to as Nationally Only Companies (NOCs) have lesser enthusiasm, lesser perception about the advantages and lesser support for IFRS adoption than Companies doing business both nationally and internationally, referred to as National and International Companies (NAICs).

6) Differences in enthusiasm, perceptions about the advantages of IFRS and lesser support for IFRS adoption are primarily because NOCs have no international operations, and as such pay less attention to creating awareness or training about IFRS compared to NAICs. In addition, NOCs have employees with lower levels of education and exist more as limited liability, sole proprietors, unlike NAICs that exist as corporations with more financial power to finance international operations, trainings and the creation of IFRS awareness.

7) NOCs prefer GAAP more than IFRS, while NAICs prefer IFRS more than GAAP. This conclusion was reached because NOCs are interested in seeing the adoption of IFRS delayed longer or not adopted at all, unlike NAICs interested in seeing adoption completed in 3-5 years. 
8) There is a positive correlation between five factors, the advantages and disadvantages of IFRS, scope of business operation, type of business, education and job position, and the support for IFRS adoption among trading companies.

9) The advantages of IFRS overshadow the disadvantages signifying a great support for IFRS suggesting that the mandatory transition to IFRS in the USA will be accomplished come 2015.

\section{Recommendations}

Recommendations based on the findings from this study aim at offering solutions to the problem identified at the beginning of the study. The problems is the diminished likelihood and doubt that the United States transition to the International Financial Reporting Standards (IFRS) by 2015, because the goals and benchmarks for transition were not met and support was low leading to delays and postponement of schedules for adoption (Asongu, 2008; Barniv \& Fetykov, 1997; Chasen, 2010; Legotte (2012). Thus, an investigation of the awareness of IFRS and two other factors (a) the perceived advantages or supporting factors to IFRS adoption and (b) the disadvantages or obstacles to adoption, as co-determinant factors to IFRS support and mandatory adoption by 2015 was compelling as the purpose of this study, in line with the views of other researchers (Deloitte, 2011; Deloitte, 2008; Lejeune, 2010).

The goal was to reveal factors that are essential and critical for a strong support and adoption of IFRS by 2015, as the bases for designing a Predictive IFRS Transition Model (AITM). AITM displays a set of factors and actions critical for rallying support and meeting adoption schedule mandates, which constitute the cream of the recommendations. The assumption is that the 2015 outcome will depend on how the forces for and against IFRS outweigh each other, in other words, how the advantages overshadow the disadvantages in mustering and creating greater support for IFRS, and vice versa. Hence, this section presents three themes, recommendations, Awareness IFRS Transition Model (AITM), and further studies.

Five main recommendations were made.

1) Massive IFRS awareness campaign, involving educational institutions, companies and the government about the advantages and benefits of IFRS, and most importantly the scheduled adoption mandate for 2015. Campaign should focus on National Only Companies (NOCs).

2) As part of the campaign, the government should provide incentives, such as tax incentives, to defray cost of preparations and reduce the cost of conversion, training and education on IFRS to minimize complexity of conversion or enhance its understanding, which are the observed obstacles or disadvantages limiting the support for IFRS revealed by this study. Academic institutions should modify curricula to integrate essential IFRS contents and hire experienced and qualified teachers to teach them. Companies should embark on staff training and development focused on IFRS.

3) There is the need to focus companies on training and education of employees about IFRS as part of the campaign, which is necessary to create awareness and induce the preparation for the change or transition to IFRS, which until now seemed very unlikely to be achieved by 2015 because, benchmarks and support were low. It is also very important because the perception of the advantages of IFRS continues to outweigh the disadvantages, and the reality and possibility of IFRS adoption has become more glaring, stressing the need for preparation.

4) The campaign should in addition, focus on the following areas: (a) highlighting the advantages of IFRS, such as the ease of reporting and transparency of financial 
data if IFRS compared to the complexity of GAAP, (b) companies operating nationally only referred to as National Only companies (NOCs), where the support for IFRS was found to be lower than it is in companies operating nationally and internationally also, referred to as National and International Companies (NAICs), and (c) helping NOCs address the issues

5) This study most importantly recommends the use of the IFRS Awareness Transition Model (IATM) to ensure a systematic approach for mustering support and meeting benchmarks for the adoption of IFRS by 2015.

It is time for schools, companies and the United States government to take steps to create awareness and increase understanding about IFRS, given that many more other countries continue to embrace it with interest and heightened activity. Knowledge of the possible effects of implementing IFRSs in advance can only be the most appropriate course of action in preparation for a response to a transition in 2015 if mandated by Security and Exchange Commission.

\section{IFRS Awareness Transition Model (IATM)}

IATM contains eight cardinal elements, the awareness campaign, the educational institutions, companies, governments, the advantage/disadvantages elements, support, benchmark, and 2015. It also indicates the roles of the educational institutions, companies, governments in the process. The IATM model is based on the assumption that if the educational institutions, companies, governments, effectively play their roles indicated in Figure 18 below, the effect of the disadvantages of IFRS will become very insignificant and make way for meeting the support benchmarks and accomplishing the IFRS goal for 2015 in the United States.

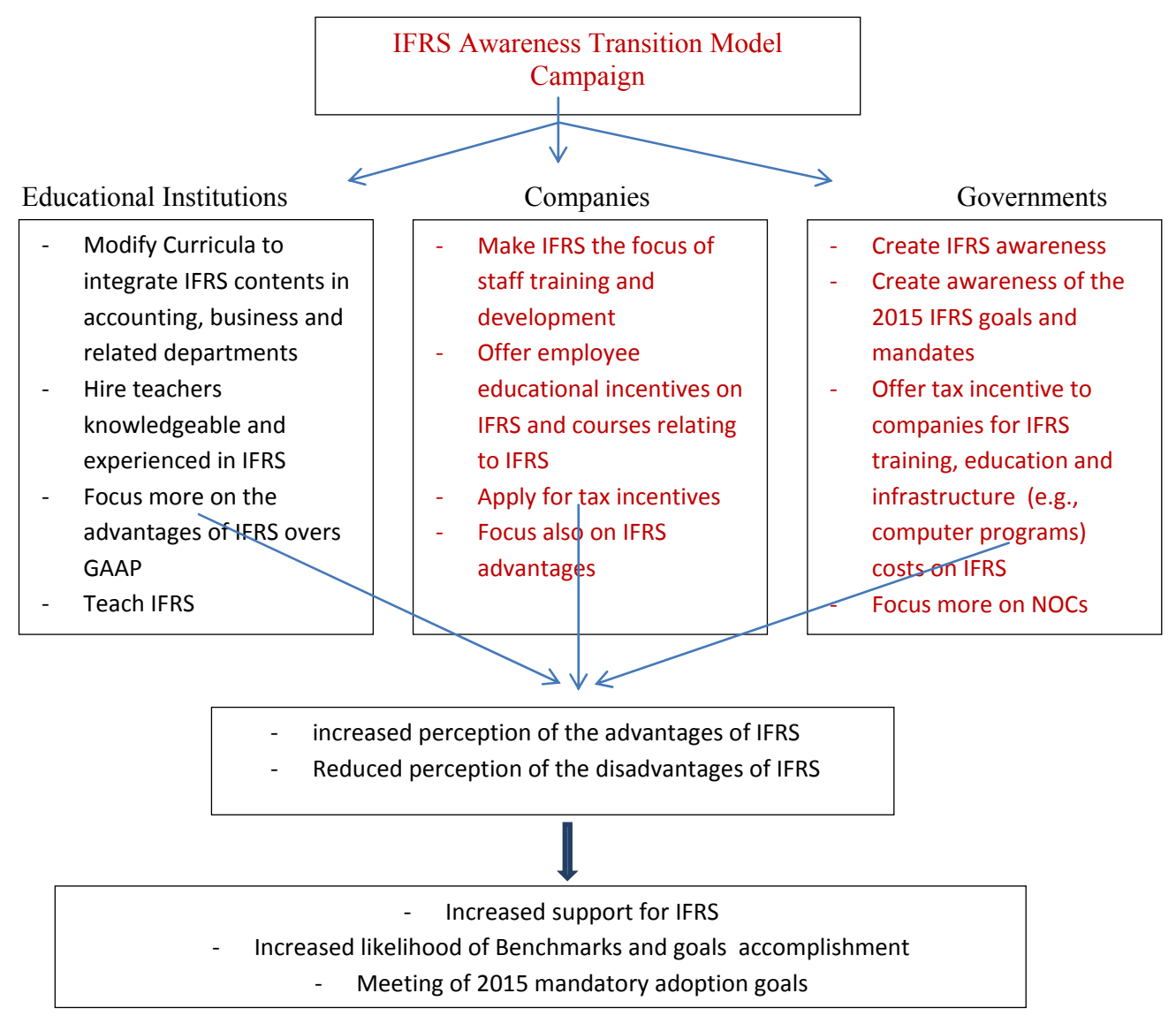

Figure 3: Awareness IFRS Transition Model (AITM) (Walid Masadeh, 2013) 


\section{Further Studies}

Results from this this study confirmed that the largest interest in adopting IFRSs lies in National and International Companies (NAICs), mainly in financial services far more than in health services, and consumer and industrial products, unlike found by the study by Deloitte (2008) This is not surprising because this study focused on trading companies only. However, more studies will be necessary to clarify the support for IFRS in these companies comparative between NOCs and NAICs, as was done in this study. Also necessary are clarifications on the influence of age, gender and type of industry on the support for IFRS, which according to results from this study had no significant effects. Though not included in this study, it will be interesting to know the impact of culture on the support for IFRS, on the strength of the statement by Deloitte (2008), that "Perhaps the biggest challenge is a cultural one. Bringing together accounting standards may be easier than coordinating the variety of cultural differences and perspectives involved in interpreting and applying IFRSs... companies, auditors, regulators, and users will need ...greater professional judgment and less reliance on detailed rules and bright lines" (p. 4).

Above all, this study first and foremost recommends further studies on IFRS using the Awareness IFRS Transition Model (AITM), and noting the assumption that the elements can be quantified in a way and regressed linearly for determining support and prediction IFRS adoption likelihood.

\section{References}

Albers, J. A., \& Brewer, S. (2003). Knowledge Management and the Innovation Process: The Eco-Innovation Model. Journal of Knowledge Management Practice, 15, 403-422.

Albers, J. A., \& Brewer, S. (2003). Knowledge management and the innovative process: The eco-innovative model. Retrieved from Journal of Knowledge Practice : http://www.tlainc.com/articl52.htm

Asongu, J. J. (2008). The ramifications of global accounting diversity and the movement towards the harmonization of accounting standards. Journal of Business and Public Policy, 2(2), 48.

Barniv, R., \& Fetykov. (1997). Attitudes of CPAs and financial executives toward harmonization of international accounting standards. Journal of international accounting standards, 6(2) 149.

Bolman, L. G., \& Deal, T. E. (2003). Refraiming organizations: Artistery,choice, and leadership. San Francisco, CA: Jossey-Bass.

Bou-Liusar, J. C., \& Segarra-Cypress, m. (2006). Strategic knowledge management tranfer and its implications for competitive advantage: An integrative conceptal framework. Journal of knowledge management, 10(40), 100-102.

Burke, W. W. (1992). Organizational Development: A process of learning and changing. NY: ADDISON-WESLEYPublication Inc.

Byers, R. N. (2012). Implications of transitioning to IFRS for financial analysts in the oil and gas production industry. Capella University). ProQuest Dissertations and Theses, 138. Retrieved from http://search.proquest.com/docview/925634882?accountid=34899 (925634882)

Chasen, E. (2010). Half of U.S. execs want to use IFRS early-survey. Retrieved from http://www.reuters.com/article/2010/03/09/ifrs-survey-idUSN0919332520100309

Choi, F. D., \& Meek, G. K. (2008). International Accounting. New York: Pearson Education. 
Daske, H., Hail, L., Leuz, C., \& Verdi, R. (2008). Mandatory IRFS reporting around the world: Early evidence on the economic consequences. Retrieved from http://ssrn.com/ abstract $=1024240$

Deloitte . (2011). IAS plus monthly news. Retrieved from Deloitte: IAS PLUS. Retrieved from http://www.iasplus.com/en/news/2011/June/news6721

Deloitte. (2008). 2008 IFRS Survey. Retrieved from http://www.iasplus.com/dttpubs/ 2008ifrssurvey.pdf or http://www.iasplus.com/en/binary/dttpubs/2008ifrssurvey.pdf/view

Doupnik, T., \& Perera, H. (2007). International Accounting. New York: MacGraw-Hill.

Forgaty, M. (2008). International financial reporting standards: Is the world ready for convergence. Catalyst, 2(1), 10.

Haina, S. (2008). Economic consequences of voluntary adoption of unilateral financial reporting standards. Retrieved from http://search.proquest.com.libproxy.edmc.edu/pqdtft/ docview/304826971/previewPDF/12E34A99FD16A952523/1 ?accountid=34899

Half, R. (2009). International finance reportingstandards for united states: Making the talent transition. Retrieved from http://www.iasplus.com/resources/0907rhalfreport.pdf

Hermastho, B. (2009). Critical success factors for TQM implimentation and their impact on performance of SMEs. International Journal of Productivity and Performance Management, $58(3) 215-237$.

Hill, D. A. (2008). What makes total quality management work. Retrieved from Proquest Dissertations:

http://search.proquest.com.libproxy.edmc.edu/pqdtft/docview/304832602/abstract/12E4155B 6CD1CDFE4B5/20? accountid=34899

Insik, C. (2009). Exploring the relationship between dimensions of organizational learning and firms' financial and knowledge performance in the Korean business context. Retrieved from http://search.proquest.com.libproxy.edmc.edu/pqdtft/docview/304898448/fulltextPDF/ 12E465C4A3B29DF4C0F/5?accountid=34899

International Accounting Standards Board. (2009). IASB and the IASC foundatiion: Who we are and what we do. Retrieved from http://www.iasb.org/NR/rdonlyres/95c54002-7796-4e23

Investopedia. (2012). Definition of international financial reportinf standards-IFRS. Retrieved from http://www.investopedia.com/terms/i/ifrs.asp\#axzz22MEjXJbn

Joseph, C. (2011). 5 factors and events that can affect the stock market. Retrieved from Ehow Money: http://www.ehow.com/list_5973922_factors-can-affect-stock-market.html

Kent (2012) Force Field Analysis Retrieved from http://literacy.kent.edu/eureka/ strategies/force_field_analysis.pdf

Kurt, L. (2012). Force field analysis and diagram-Kurt Lewin. Retrieved from http://www.valuebasedmanagement.net/methods_lewin_force_field_analysis.html

Legotte, L.C. (2012) IFRS Adoption in the United States in 201. Retrieved from Global Executive Training Association, http://globalexecutives.org/global-articles/ifrs-adoptionin-the-united-states-in-2015/

Lejeune, A. T. (2010). Examination of Louisana certified public accountants' perceived education needs related to international financial reporting standards. Retrieved from Proquest Dissertations and Theses: http://search.proquest.com.libproxy.edmc.edu/pqdtft/ docview/817403811/fulltextPDF/13080559BF992D200C/5?accountid=34899

Mazboudi, M. (2012). Accounting choices under IFRS and their effect on over-investment in capital expenditures. The University of Iowa). ProQuest Dissertations and Theses, , 69. Retrieved from http://search.proquest.com/docview/1030282676?accountid=34899 (1030282676) 
Michael, J. (2011). Advantages to adopting IFRS. Retrieved from http://bcgcompany.com/ blog/ifrs/tag/mandatory-adoption-of-ifrs/

National Coordinator for Health Information Technology. (2011). Electronic health records and meaningful use. Retrieved from http://healthit.hhs.gov/portal/server.pt?open=512\& objID $=2996 \&$ mode $=2$

Neel, M. J. (2011). International financial reporting standards (IFRS) and the institutional environment: Their joint impact on accounting comparability. Texas A\&M University). ProQuest Dissertations and Theses, 67. Retrieved from http://search.proquest.com/docview/ 908885445 ?accountid=34899 $(908885445)$

New Creation Information Technologies. (2011). Healthcare Knowledge Management. Retrieved from http://newcreationit.com/healthcare-management/data-analysis

Pearce, J. A., \& Robinson, R. B. (2007). Strategic Management: Formulation, Implementation, and Control. New York: MacGraw- Hill.

Peng, G. Z. (2009). Multinational Corporation's International Experience and Subsidiary Performance: Learning, Knowledge Tranfer and Dynamic Capability Perspectives. Retrieved from Proquest Dissertations: http://search.proquest.com.libproxy.edmc.edu/pqdtft/docview/ 305108227/12E4608E8651267540D/2?accountid=34899

PricewaterhouseCoopers (PCW). (2011). TransitionIFRS tools and methodology. Retrieved from http://www.pwc.com/us/en/issues/ifrs-reporting/ifrs-methodology.jhtml

PricewaterhouseCoopers. (2009 B). IFRS readiness series. Retrieved from www.pwc.corn/ usifrs

Propper, M., \& Lipshitz, R. (1998). Organizational learning mechanisms: A structural cultural approach to organizational learning. Journal of Applied Behavioral Science, 34(2), 161-179.

Quality Assurance. (2011). TQM Model. Retrieved from http://www.quality-assurancesolutions.com/TQM-Model.html

Schroeder, R. G., Clark, M. W., \& Cathey, J. (2009). Financial Accounting Theory and Analyis: Text and Cases. NJ: John Wiley \& Sons Inc.

Sila, I. (2007). Examining the effects of contextual factors on TQM and performance through the lens of organizational theory: an empirical study. Journal of Operations MAnagement, 25(1), 83-109.

Skyrme, D. (2002). Knowledge Management: Approaches and Policies. Retrieved from http://www.providersedge.com/docs/km_articles/KM_-_Approaches_and_Policies.pdf

Smith, W. (2011). Organizational force field analysis. Retrieved from Chron: Small Business: http://smallbusiness.chron.com/organizational-force-field-analysis-4861.html

U.S. Office of Personnel Management. (2004). Health information technology (HIT) Transparency. Retrieved from OPM.gov: http:/www.opm.gov/insure/health/reference/ hittransparency.asp

Vann, C. E. (2012). An investigation of the value relevance of accounting information, IFRS, institutional factors, culture, and corporate governance: International evidence. The University of Memphis). ProQuest Dissertations and Theses, , 172. Retrieved from http://search.proquest.com/docview/1034261532? accountid=34899. (1034261532).

Wali, S., \& Younes, B. (2010). The effect of TQM implimentation on firm performance in the Tunisian context. International Journal of Prductivity, 5(1), 60-74. 


\section{Macrothink}

Wallace, R. B. (2010). The relationship of organizational learning to knowledge management and its impact on innovation. Retrieved from http://search.proquest.com.libproxy.edmc.edu/ pqdtft/docview/853329821/12E4EFC698E1B0E9B44/1?accountid=34899

Yip, W. Y. (2010). The effects of IFRS adoption on cross-border information comparability and economic activity. The Chinese University of Hong Kong (Hong Kong)). ProQuest Dissertations and Theses, 93. Retrieved from http://search.proquest.com/docview/912364244? accountid=34899. $(912364244)$

\section{Copyright Disclaimer}

Copyright reserved by the author(s).

This article is an open-access article distributed under the terms and conditions of the Creative Commons Attribution license (http://creativecommons.org/licenses/by/3.0/). 